\title{
Announcement
}

\section{Pamela Patton wins Prestigious Bishko Prize for Article in Medieval Encounters}

The Bishko Memorial Prize for 2020 has been awarded for an article in Medieval Encounters to Pamela Patton of the Index of Medieval Art, Princeton University. The award-winning article, "Demons and Diversity in León", appeared in Medieval Encounters 25.1-2 (2019), pp. 150-179. It examines the unusual depiction of Satan as a dark-skinned figure in a wall painting in the socalled Panteón de los Reyes of San Isidro in León, arguing that this unorthodox portrayal constituted an innovative and intervisual response to a twelfth-century palatine viewership preoccupied with its dynastic and political position within León and beyond. The article was published as part of a special issue, "The Medieval Iberian Treasure in the Context of Cultural Interchange," guest edited by Therese Martin of the Consejo Superior de Investigaciones Científicas, Madrid.

Given annually since 2003 by the Association for Spanish and Portuguese Historical Studies, the Bishko Prize is awarded for the best article in the field of medieval Iberian history written by a North American scholar. It honours Professor Charles Julian Bishko, the distinguished historian of medieval Iberia who taught for 39 years at the University of Virginia.

Articles appearing in Medieval Encounters have previously won the prize. The prize for 2012 was awarded to Thomas Barton for his article, "Muslims in Christian Countrysides: Reassessing Exaricus Tenures in the Crown of Aragon" (Medieval Encounters 17.3 (2011), pp. 233-320), while the prize for 2011 was awarded to Olivia Remie Constable for her article, "Regulating Religious Noise: The Council of Vienne, the Mosque Call and Muslim Pilgrimage in the Late Medieval Mediterranean World" (Medieval Encounters 16.1 (2010), pp. 64-95). 